\title{
PENGEMBANGAN SISTEM AKUISISI DATA ARUS, TEGANGAN, DAYA DAN TEMPERATUR PADA PEMBANGKIT LISTRIK TENAGA SURYA
}

\author{
Reza Pratama ${ }^{1}$, Muhamad Ali ${ }^{2}$ \\ ${ }^{12}$ Jurusan Pendidikan Teknik Elektro, Fakultas Teknik, Universitas Negeri Yogyakarta \\ email : rezapratama5701@gmail.com
}

\begin{abstract}
Electric energy in Indonesia is increasing while it is not balanced with the production of electrical energy. Solar power plant is one solution to increase the demand of electric energy using solar cell as the main power source. The main purpose of this studies are: (1) design and build an acquisition system that can read the current, voltage, temperature and power in the solar cell and can store data directly and (2) measure the performance of data acquisition system current, voltage, temperature, and power generated by solar cells in real-time as well as test the data storage of measurement results and readings directly. Final stage making this project begins with the identification and needs analysis used, schematic circuit controller system design, realtime display design with Delphi7, storage process design, and testing phase. The measurement data is obtained by testing the results of the design of the design according to the performance of the tool. After the final project testing phase is able to display the performance results of solar cells in real-time and can save data directly in accordance with the performance of the tool. Test results for three days obtained an error of $3.4 \%$ on current measurements, $4.4 \%$ on voltage measurement and $6.3 \%$ on temperature measurement. From the data of the test results can be concluded this study is able to provide information quickly and accurately in order to determine the conduct of treatment or further improvement.
\end{abstract}

Keywords: acquisition, real-time display, solar cell

\begin{abstract}
ABSTRAK
Kebutuhan energi listrik di Indoensia semakin meningkat tetapi tidak diimbangi dengan produksi energi listrik yang ada. Pembangkit Listrik Tenaga Surya merupakan salah satu solusi untuk meningkatkan kebutuhan energi listrik. Pembangkit listrik ini menggunakan solar cell sebagai sumber pembangkit listrik utama. Tujuan utama dari penelitian ini yaitu (1) merancang dan membangun sebuah sistem akuisisi yang dapat membaca arus, tegangan, suhu, dan daya pada solar cell serta dapat menyimpan data secara langsung dan (2) mengukur unjuk kerja sistem akuisisi data arus, tegangan, suhu, dan daya yang dihasilkan oleh solar cell secara real-time serta menguji penyimpanan data hasil pengukuran dan pembacaan secara langsung. Tahap pembuatan proyek akhir ini dimulai dengan identifikasi dan analisis kebutuhan yang digunakan, desain rangkaian skematik system controller, desain tampilan secara real-time dengan Delphi7, perancangan proses penyimpanan, dan tahap pengujian. Data hasil pengukuran diperoleh dengan menguji hasil pembuatan rancang bangun yang sesuai dengan unjuk kerja alat. Setelah dilakukan tahap pengujian proyek akhir ini dapat menampilkan hasil kinerja dari solar cell secara real-time dan dapat menyimpan data secara langsung sesuai dengan unjuk kerja alat. Hasil pengujian selama tiga hari didapatkan error sebesar 3,4\% pada pengukuran arus, 4,4\% pada pengukuran tegangan dan $6,3 \%$ pada pengukuran temperatur. Dari data hasil pengujian dapat disimpulkan penelitian pengembangan ini mampu memberikan informasi yang cepat dan akurat untuk menentukan dilakukannya perawatan atau perbaikan lebih lanjut.
\end{abstract}

Kata kunci: akuisisi, tampilan real-time, solar cell, 


\section{PENDAHULUAN}

Saat ini energi listrik memiliki kontribusi yang sangat besar bagi kehidupan masyarakat. Setiap rumah, pabrik, toko, jalan semua menggunakan listrik sebagai sumber energi. Kebutuhan energi listrik setiap tahunnya semakin meningkat sedangkan hal tersebut tidak diimbangi dengan produksi energi listrik yang ada di Indonesia.

Indonesia merupakan Negara Kepulauan yang terdiri dari \pm 17.508 pulau dengan garis pantai $\pm 810.000 \mathrm{~km}$ dan luas 3,1 juta $\mathrm{km} 2$ dengan jumlah desa yang lebih dari 65.000 desa yang tersebar di belasan ribu pulau tersebut, hanya kurang dari setengahnya yang telah menikmati jaringan listrik, sebagian besar dari mereka masih menggunakan lampu minyak tanah/petromak untuk penerangan. Bahkan dibeberapa daerah di Indonesia masih belum terdapat sumber listrik seperti daerah terpencil, pegunungan, pulau dan daerah lain yang tidak tesentuh oleh jaringan listrik.

Indonesia yang terletak di garis khatulistiwa memiliki potensi penyinaran matahari yang besar yaitu $4,80 \mathrm{kWh} / \mathrm{m} 2 /$ hari. Matahari bersinar selama 12 jam setiap hari, sepanjang tahun dengan intensitas yang tinggi. (Jurnal Energi Kementrian ESDM, 2016: 20) Pembangkit Listrik Tenaga Surya (PLTS) merupakan solusi yang tepat untuk memanfaatkan potensi sinar matahari di Indonesia yang berlimpah. Daya dari sistem surya sangat terkenal dengan keramahan lingkungannya, tanpa menggunakan bahan bakar minyak, tidak akan menimbulkan kebisingan, dan polusi serta sumber daya pembangkitannya yang melimpah. Dibandingkan dengan Jerman, Jepang, dan Amerika Serikat yang berada pada daerah subtropis dengan 4 musimnya, mereka sudah memanfaatkannya lebih dulu dari kita. Kelemahan dari PLTS ini adalah pada saat malam hari pembangkit tersebut tidak dapat membangkitkan energi listrik karena tidak ada matahari pada saat malam hari oleh karena itu dibutuhkan perangkat pembantu seperti
Accumulator dan Solar Charge Control untuk menyimpan serta mengendalikan energi listrik agar dapat digunakan pada saat tidak terdapat sumber matahari.

Sel Surya fotovoltaik merupakan suatu alat yang dapat mengubah energi sinar matahari secara langsung menjadi energi listrik. Pada asasnya sel tersebut merupakan suatu dioda semikonduktor yang bekerja menurut proses khusus yang dinamakan proses tidak seimbang (non-equilibrium process) dan berlandaskan efek (photovoltaic effect) (Abdul Kadir, 1995: 369).

Pada prinsipnya, pembangkitan listrik tenaga surya terdiri dari sekelompok foto sel yang mengubah sinar matahari menjadi gaya gerak listrik (ggl) untuk mengisi batrai aki (B). Dari baterai aki (B), energi listrik dialirkan ke pemakai. Pada waktu banyak sinar matahari (siang hari), baterai aki (B) diisi oleh foto sel. Tetapi pada saat malam hari, foto sel tidak menghasilkan energi listrik, maka energi listrik diambil dari baterai aki (B) tersebut. (Djiteng Marsudi, 2005: 132)

Baterai aki merupakan sumber arus searah yang digunakan dalam pusat listrik. Baterai aki harus selalu diisi melalui penyearah (rectifier). Kutub negatif dari baterai sebaiknya ditanahkan untuk memudahkan mendeteksi gangguan hubungan tanah pada instalasi arus searah. Ada 2 macam baterai aki yang dapat digunakan di pusat listrik, yaitu dengan kutub timah hitam dan baterai basa yang menggunakan nikel cadmium sebagai kutub. (Djiteng Marsudi, 2005: 33)

Perangkat utama untuk menghasilkan energi listrik yang terdapat pada PLTS adalah Panel Surya atau sering disebut Solar Cell. Panel Surya atau Solar Cell tersebut adalah komponen yang mengkonversi energi dari matahari menjadi energi listrik. Karena berhubungan dengan harga solar cell dan komponen pendukung yang begitu mahal untuk mendirikan sebuah PLTS maka perlu adanya perawatan agar komponen-komponen yang terdapat pada PLTS dapat bertahan dalam jangka waktu yang lama. Salah satu dasar untuk 
melakukan perawatan atau perbaikan adalah kondisi hasil kinerja solar cell. Waktu yang dibutuhkan untuk mendapatkan informasi kondisi solar cell adalah salah satu faktor penyebab kurang optimalnya kinerja solar cell.

Sistem akuisisi yang dirancang dalam tugas akhir ini adalah sistem yang dapat mengakuisisi data keluaran dari solar cell dengan berbasis komputerisasi. Data yang telah dikirimkan ke komputer selanjutnya akan diproses dengan menggunakan aplikasi Delphi 7, sehingga data-data hasil dari akuisisi tersebut dapat ditampilkan pada sebuah komputer sebagai monitoring serta dapat disimpan secara langsung pada komputer. Hasil tampilan yang berupa data maupun kondisi solar cell sehingga dapat dijadikan sebagai refrensi kepada operator untuk dapat mengambil keputusan berdasarkan data atau kondisi yang ditampilkan sesuai dengan karakteristik solar cell. Dengan menggunakan perangkat komputer diharapkan sistem ini mampu bekerja dengan respon waktu yang lebih cepat setiap waktu.

\section{METODE}

Metode yang digunakan dalam penelitian "Pengembangan Sistem Akuisisi Data Arus, Tegangan, Daya dan Temperatur Pada Pembangkit Listrik Tenaga Surya" ini menggunakan pendekatan penelitian dan pengembangan atau Research and Development. Tahap-tahap penelitian mengacu pada model penelitian pengembangan model Borg and Gall yang dijelaskan dalam Gambar 1 berikut:

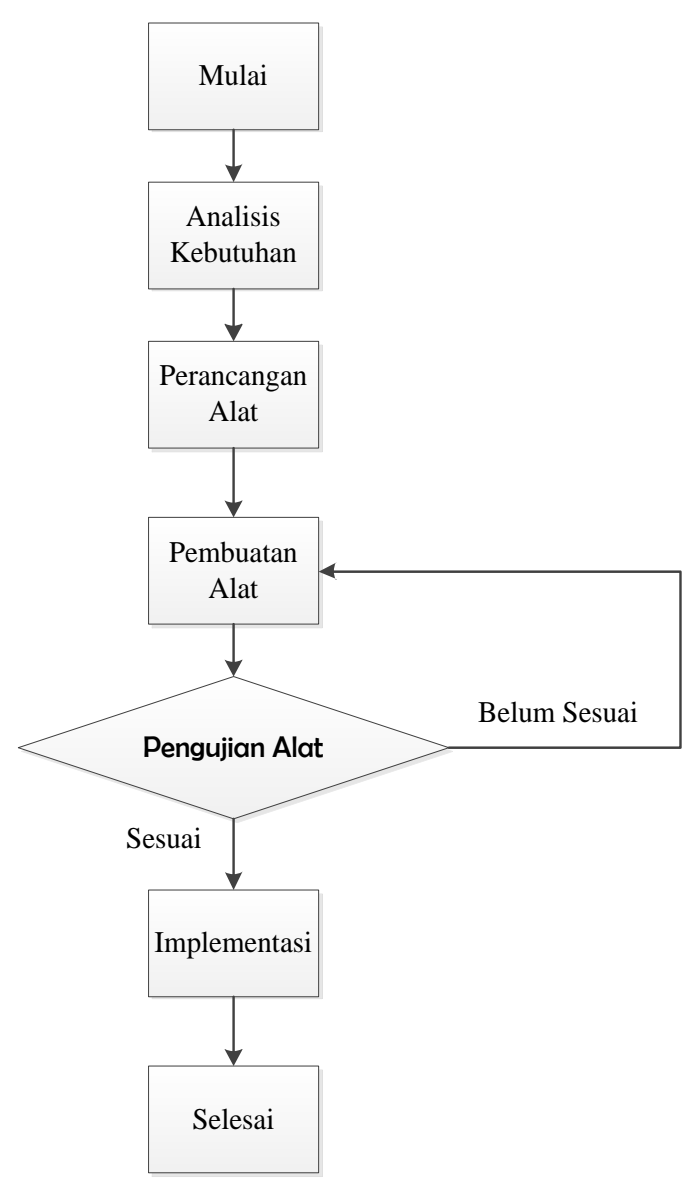

Gambar 1. Flowchart Pelaksanaan

Berdasarkan hasil survey pada pembangkit listrik tenaga surya komponen kebutuhan untuk membangkitkan energi listrik terdiri dari solar cell sebagai penghasil energi listrik, pengatur pengisian daya untuk mengatur waktu pengisian daya pada baterai, dan accumulator atau baterai guna untuk menampung energi listrik.

Setelah dilakukan analisis kebutuhan, selanjutnya dilakukan perancangan alat. Untuk mengimplementasikan alat tersebut diperlukan komponen: 1) Solar Cell, sebagai penghasil tenaga listrik. 2) Pengatur Pengisian Baterai, sebagai pengatur pengisian daya pada baterai. 3) Accumulator, sebagai penampung daya hasil pembangkitan tenaga listrik. 4) Sensor Arus ACS 712, sebagai pembaca arus hasil pembangkitan. 5) Sensor Tegangan, sebagai pembaca tegangan hasil pembangkitan. 6) Sensor Temperatur, sebagai pembaca temperatur pada solar cell. 7) Microcontroller, 
sebagai penghubung pengiriman data antara sensor-sensor dengan perangkat lunak. 8) Perangkat Lunak, sebagai pemantau data hasil pembangkitan dan penyimpan data hasil pembangkitan secara otomatis. Gambar rancangan rangkaian ditampilkan pada Gambar 2.

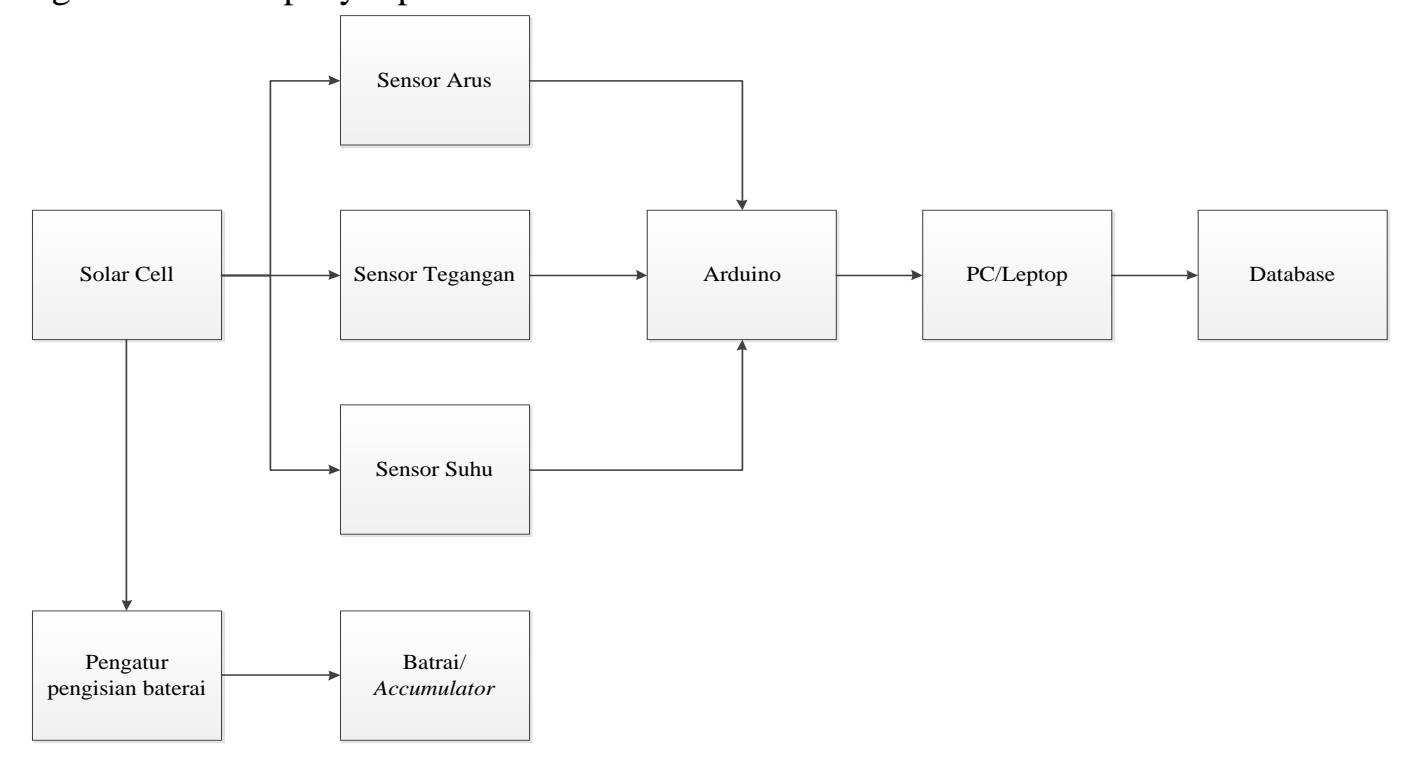

Gambar 2. Rancangan Rangkaian

Selanjutnya adalah tahap pembuatan yang terdiri dari 1) Pembuatan rangkaian skematik alat. 2) Pembuatan program untuk sensorsensor. 3) Pembuatan tampilan perangkat lunak. 4) Pembuatan program penyimpanan database secara otomatis 5) Pengemasan alat.

Pengujian dilakukan guna untuk menguji masing-masing komponen dapat bekerja sesuai yang diinginkan dan dapat dilakukan analisa jika terjadi kesalahan proses kerja pada alat tersebut.

Penerapan alat dilakukan jika alat bekerja dengan baik dan dapat diimplementasikan pada keadaan yang sesungguhnya yaitu pada pembangkit listrik tenaga surya

\section{HASIL DAN PEMBAHASAN}

Tempat pengujian dan pengambilan data dilakukan di Gedung LPTK lantai 4 Universitas Negeri Yogyakarta. Pengujian dilakukan dengan menggunakan sel surya dengan kemampuan $150 \mathrm{WP}$ untuk menguji kinerja alat tersebut dalam keadaan yang sesungguhnya. Variabel yang dibandingkan adalah perubahan tegangan, arus, dan suhu pada sensor arus, sensor tegangan, dan sensor temperature yang akan ditampilkan secara realtime pada komputer dengan perubahan tegangan, arus dan suhu yang diukur menggunakan amperemeter, voltmeter dan thermometer. Serta menguji hasil data secara real-time yang dapat disimpan dalam sebuah database. Kemudian menghitung error yang terjadi dari sensor dengan alat ukur yang telah diuji. Dari hasil pengujian dan pengukuran diharapkan dapat mengetahui kinerja dari pengembangan alat sistem akuisisi data pada pembangkit listrik tenaga surya serta dapat menganalisis error yang terjadi agar didapatkan data yang akurat.

Tabel rata-rata pengukuran hari pertama sampai ketiga ditampilkan pada Tabel 1 . 
Tabel 1. Hasil Rata-rata Pengukuran Hari Pertama Sampai Hari Ketiga

\begin{tabular}{|c|c|c|c|c|c|c|c|c|c|c|}
\hline \multirow[b]{2}{*}{ Jam } & \multicolumn{3}{|c|}{ Arus $(\mathrm{mA})$} & \multicolumn{3}{|c|}{ Tegangan (V) } & \multicolumn{3}{|c|}{$\operatorname{Suhu}\left({ }^{\circ} \mathrm{C}\right)$} & \multirow{2}{*}{$\begin{array}{l}\text { Daya }(\mathrm{mW}) \\
\text { Perhitungan }\end{array}$} \\
\hline & Sensor & $\begin{array}{l}\text { Alat } \\
\text { Ukur }\end{array}$ & Error & Sensor & $\begin{array}{l}\text { Alat } \\
\text { Ukur }\end{array}$ & Error & Sensor & $\begin{array}{l}\text { Alat } \\
\text { Ukur }\end{array}$ & Error & \\
\hline 09:00 & 3022,3 & 2940 & $2,8 \%$ & 14,25 & 14,7 & $3,2 \%$ & 36 & 33,6 & $7,2 \%$ & 48282,6 \\
\hline 09:30 & 3389 & 3263,3 & $3,8 \%$ & 14,4 & 14,9 & $3,5 \%$ & 37,3 & 35,3 & $5,7 \%$ & 54572,1 \\
\hline $10: 00$ & 3433 & 3353,3 & $2,4 \%$ & 14,7 & 15,1 & $2,7 \%$ & 40,7 & 37,9 & $7,4 \%$ & 58711,41 \\
\hline $10: 30$ & 2885,3 & 2766,7 & $4,3 \%$ & 14,3 & 14,9 & $4,2 \%$ & 39 & 36,9 & $5,7 \%$ & 47270,11 \\
\hline $11: 00$ & 3531 & 3403,3 & $3,7 \%$ & 14 , & & $4,8 \%$ & 39,3 & 37,2 & $5,6 \%$ & 59412,9 \\
\hline $11: 30$ & 3278,3 & 3163,3 & $3,6 \%$ & 14 & 1 & $5,5 \%$ & 39 & 37,3 & $6,4 \%$ & 53378,39 \\
\hline $12: 00$ & 3401 & 3293,3 & $3,3 \%$ & 14,5 & 15,2 & $4,8 \%$ & 39,7 & 37,4 & $6,1 \%$ & 56745,39 \\
\hline $12: 30$ & 3594,7 & 3490 & $3 \%$ & 14,6 & 15,2 & $4,1 \%$ & 40,3 & 37,6 & $7,2 \%$ & 61002,13 \\
\hline $13: 00$ & 3675,7 & 3523,3 & 4,3 & 14 & 1. & 4, & 41 & 38,3 & $7,1 \%$ & 98 \\
\hline $13: 30$ & 3452,3 & 3346,7 & $3,2 \%$ & 14,6 & 15,4 & $5,5 \%$ & 40,3 & 37,9 & $6,3 \%$ & 56582,45 \\
\hline 14:00 & 3403,7 & 3286,7 & $3,5 \%$ & 14,4 & 15,3 & $6,2 \%$ & 38,3 & 36,5 & $4,9 \%$ & 54666,6 \\
\hline $14: 30$ & 2963,7 & 2870 & $3,3 \%$ & 14,3 & 14,9 & $4,2 \%$ & 37 & 34,8 & $6,3 \%$ & 45115,73 \\
\hline 15:00 & 2958 & 2856,7 & $3,5 \%$ & 14,1 & 14,7 & $4,2 \%$ & 36 & 33,9 & $6,2 \%$ & 42250,94 \\
\hline $\begin{array}{l}\text { Rata- } \\
\text { Rata }\end{array}$ & 3306,8 & 3196,7 & $3,4 \%$ & 14,4 & 0,0 & $4,4 \%$ & 0,0 & 36,5 & $3 \%$ & 2 \\
\hline
\end{tabular}

Tabel 1 di atas merupakan tabel hasil pengukuran dari ketiga hari, perubahan hasil pembangkitan setiap jamnya dipengaruhi oleh beberapa hal yaitu kondisi cuaca, posisi solar cell serta besar intensitas cahaya matahari. Puncak dari hasil pembangkitan adalah pada pukul 11:00-13:00 karena pada jam tersebut matahari tepat di atas solar cell.

Grafik pengujian dan pengukuran arus ditampilkan pada Gambar 3.

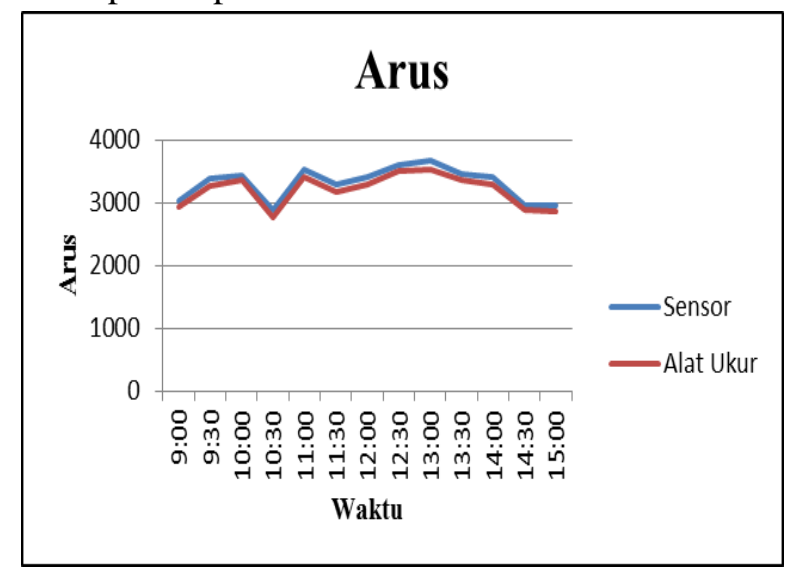

Gambar 3. Grafik Pengujian Pengukuran dan Pembacaan Arus

Grafik di atas merupakan grafik hasil rata-rata pengukuran dan pembacaan arus dari hari pertama sampai hari ketiga dengan perbandingan indikator waktu dan arus. Dari grafik di atas dapat dilihat arus maksimal yang dibaca oleh sensor adalah 3675,7 mA dengan rata-rata pembacaan $3306,8 \mathrm{~mA}$, sedangakan arus maksimal yang diukur menggunakan alat ukur adalah 3523,3 mA dengan rata-rata pengukuran 3196,7 mA.

Grafik pengujian pengukuran tegangan di tampilkan pada Gambar 4.

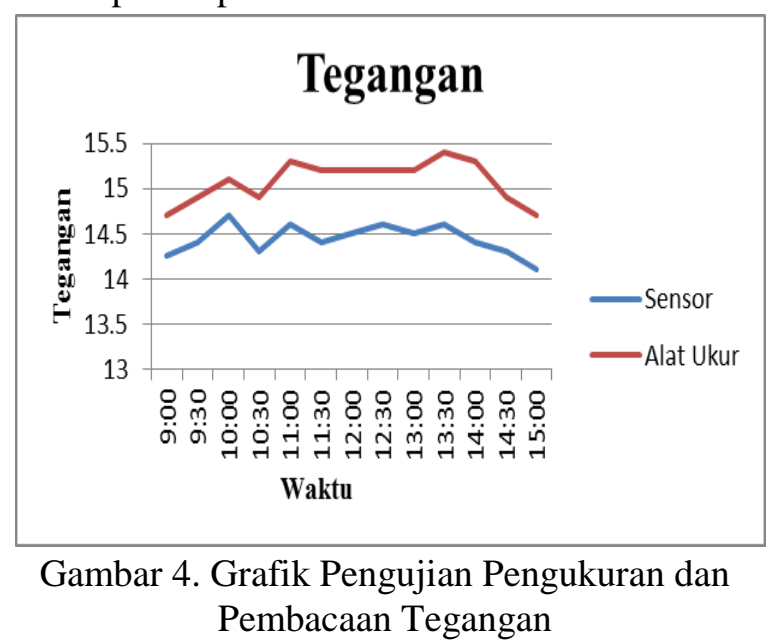

Grafik di atas merupakan grafik hasil rata-rata pengukuran dan pembacaan tegangan dari hari pertama sampai hari ketiga dengan perbandingan indikator waktu dan tegangan. Dari grafik di atas dapat dilihat tegangan maksimal yang dibaca oleh sensor adalah 14,7 $\mathrm{V}$ dengan rata-rata pembacaan $14,4 \mathrm{~V}$, sedangkan tegangan maksumal yang diukur menggunakan alat ukur adalah $15,4 \mathrm{~V}$ dengan rata-rata pengukuran $15,07 \mathrm{~V}$. 
Grafik Pengujian Pengukuran dan Pembacaan Temperature ditampilkan pada Gambar 5.

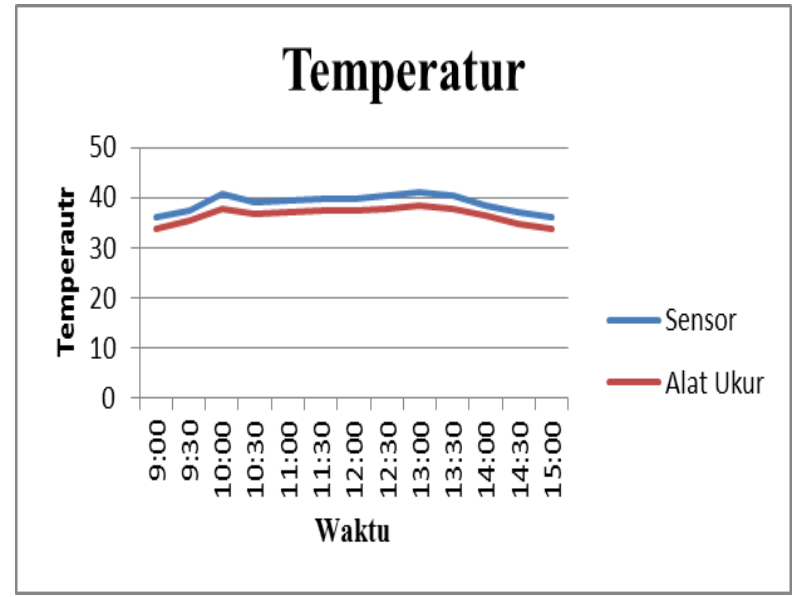

Gambar 5. Grafik Pengujian Pengukuran dan Pembacaan Temperature

Grafik di atas merupakan grafik hasil rata-rata pengukuran dan pembacaan suhu dari hari pertama sampai hari ketiga dengan perbandingan indikator waktu dan suhu. Dari grafik di atas dapat dilihat suhu maksimal yang dibaca oleh sensor adalah $41{ }^{\circ} \mathrm{C}$ dengan ratarata pembacaan $38,82{ }^{\circ} \mathrm{C}$ sedangkan tegangan maksumal yang diukur menggunakan alat ukur adalah $38,3{ }^{\circ} \mathrm{C}$ dengan rata-rata pengukuran $36,5^{\circ} \mathrm{C}$

Grafik pengujian pengukuran dan pembacaan daya ditampilkan pada Gambar 6 .

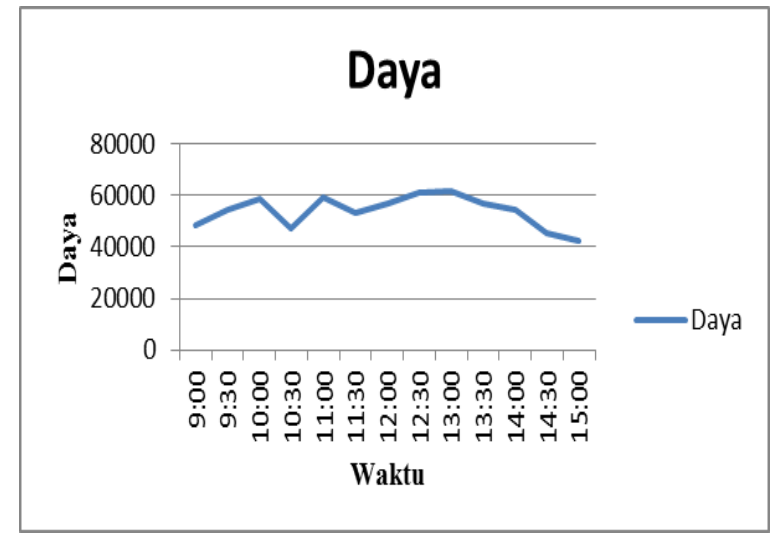

\section{Gambar 6. Grafik Pengujian Pengukuran dan Pembacaan Daya}

Grafik di atas merupakan grafik hasil rata-rata pengukuran dan pembacaan daya dari hari pertama sampai hari ketiga dengan perbandingan indikator waktu dan daya. Dari grafik di atas dapat dilihat suhu maksimal yang dibaca oleh sensor adalah 61753,98 $\mathrm{mW}$ dengan rata-rata pembacaan 53826,52 $\mathrm{mW}$.

Gambar7. Grafik Kesalahan Pembacaan Arus, Tegangan dan Temperature.

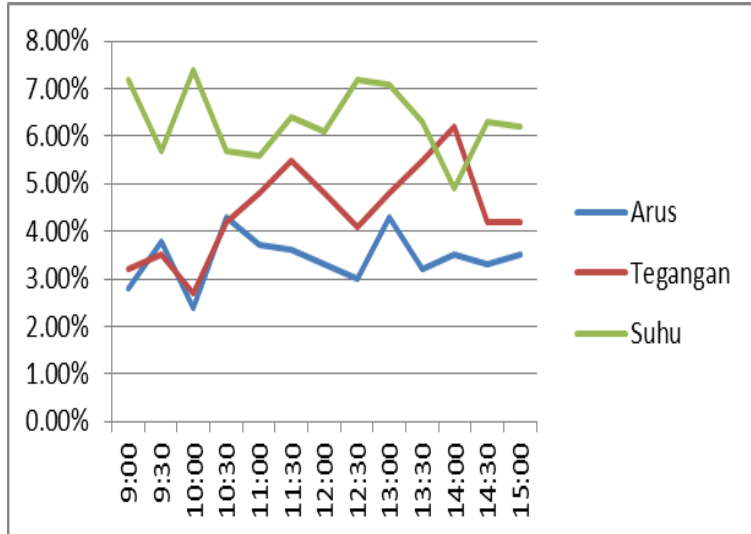

Gambar 7. Grafik Kesalahan Pembacaan Arus, Tegangan, dan Temperature

Grafik di atas merupakan grafik hasil perbandingan kesalahan pembacaan yang terjadi pada hasil pembacaan arus, tegangan, dan suhu. Rata-rata kesalahan pembacaan pada masing-masing indikator yaitu pada pembacaan sensor arus adalah $3,4 \%$, untuk sensor tegangan adalah 4,4\% sedangkan untuk sensor suhu adalah 6,3\%. Dari hasil perhitungan kesalahan pembacaan terjadi kenaikan dan penurunan tingkat kesalahan hal tersebut disebabakan oleh faktor-faktor tertentu seperti intensitas cahaya matahari, cuaca dan kondisi lingkungan.

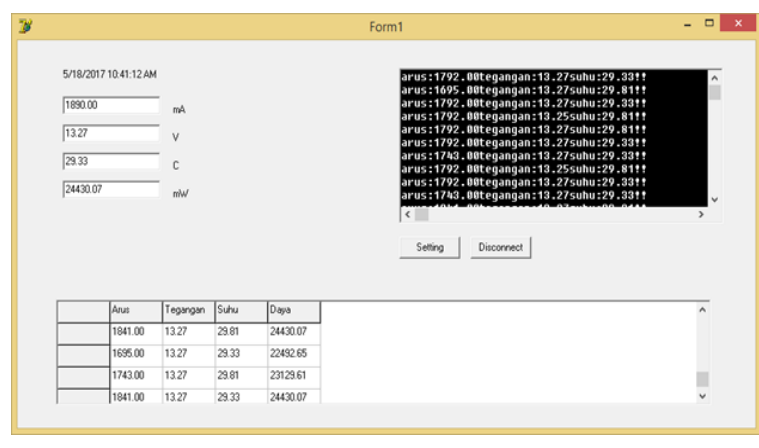

Gambar 8. Pengujian Tampilan Perangkat Lunak

Gambar di atas merupakan hasil dokumentasi pengujian tampilan perangkat lunak yang dapat menampilkan arus, tegangan, suhu, dan daya 
secara langsung yang dihasilkan oleh solar cell.

Dalam perangkat lunak terdapat beberapa komponen yaitu komponen untuk menampilkan hasil kinerja solar cell, komponen untuk menampilkan history atau hasil kinerja solar cell pada waktu sebelumnya, dan data yang dikirimkan dari sistem komunikasi serial.

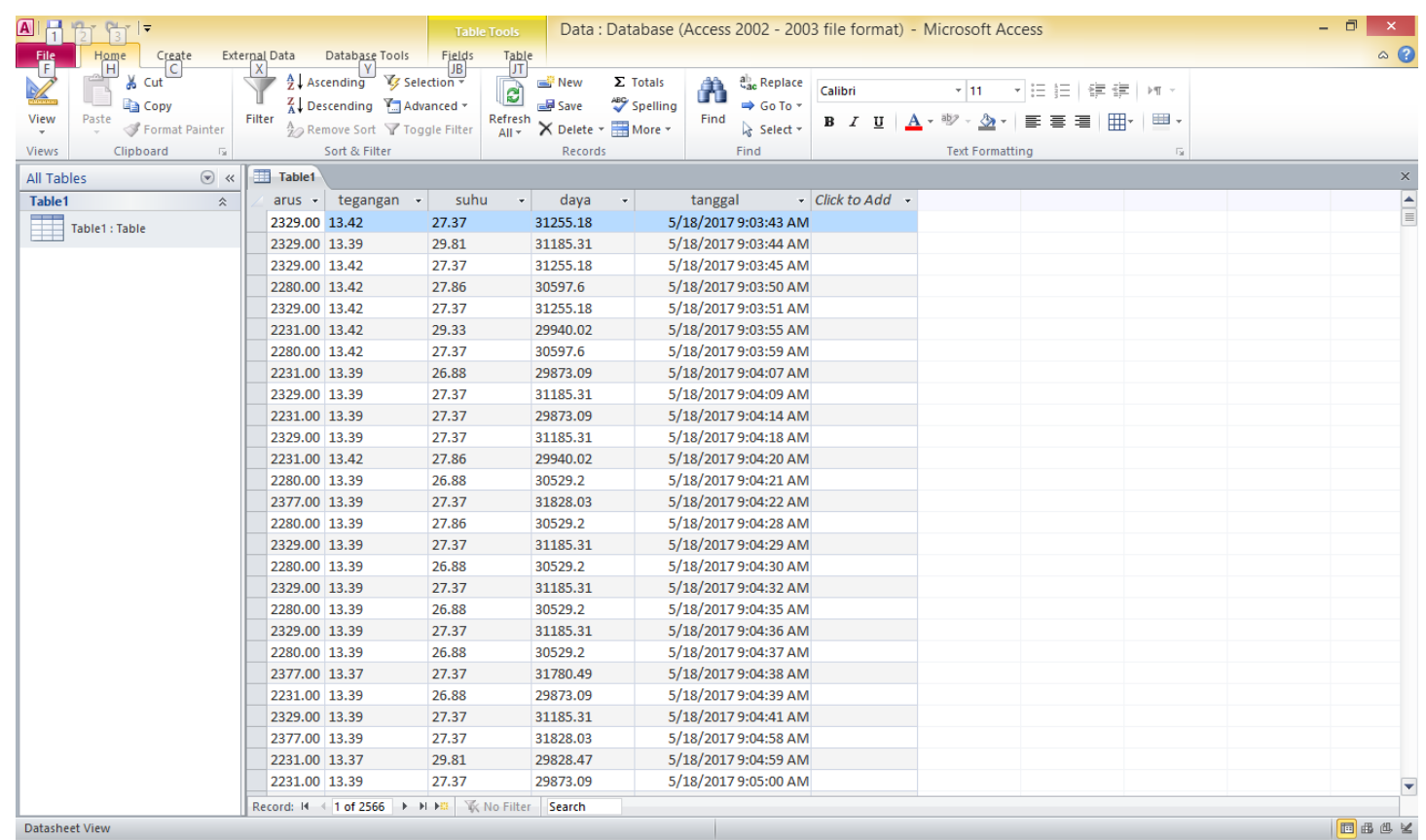

Gambar 9. Pengujian Sistem Penyimpanan Data

Gambar di atas merupakan hasil dokumentasi pengujian sistem penyimpanan data secara real-time yang direkam oleh alat setiap detik untuk mengetahui hasil kinerja dari solar cell.

\section{SIMPULAN}

Sistem akuisisi data arus, tegangan, suhu, dan daya yang dirancang mampu membaca dan menyimpan data hasil kinerja dari solar cell. Hasil pengukuran dan pembacaan arus, tegangan, suhu, dan daya yang dihasilkan solar cell dapat ditampilkan secara real-time. Data tersebut dapat disimpan dan dibandingkan antara data yang didapat dari sensor dengan data dari alat ukur. Hasil pengujian selama 3 hari yang didapatkan hasil rata-rata pengujian yaitu pembacaan sensor arus sebesar 3306,8 $\mathrm{mA}$ dan pengukuran dengan alat ukur sebesar 3196,4 mA sehingga didapatkan kesalahan pengukuran sebesar $3,4 \%$. Pembacaan sensor tegangan diperoleh sebesar 14,4 volt dan pengukuran menggunakan alat ukur sebesar 15,07 volt. Sehingga didapatkan kesalahan pengukuran sebesar $4,4 \%$. Pembacaan sensor suhu sebesar $38,82^{\circ} \mathrm{C}$ sedangkan untuk pengukuran dengan menggunakan alat ukur sebesar $36,5^{\circ} \mathrm{C}$ sehingga didapatkan kesalahan pengukuran sebesar $6,3 \%$ dan hasil tersebut sudah dirasa cukup untuk diimplementasikan dalam keadaan yang sesungguhnya. Selain itu juga hasil dari penelitian ini dapat mempermudah dalam monitoring kondisi panel surya serta dapat mengambil keputusan untuk melakukan perawatan atau perbaikan lebih lanjut.

\section{DAFTAR RUJUKAN}

Abdul Kadir. (1995). Energi sumber daya, inovasi, tenaga listrik dan potensi ekonom. Edisi kedua. Jakarta: Universitas Indonesia (UI-Press)

Ir. Djiteng Marsudi. (2005). Pembangkitan Energi Listrik. Jakarta: Erlangga 
Jaja Jamaludin Malik. (2006). Tip dan Trik Unik Delphi (Lanjutan). Yogyakarta: C.V. Andi Offset

Kementrian ESDM (2016). Program Strategis EBTKE dan Ketenagalistrikan. Jurnal Energi. Media Komunikasi Kementerian Energi dan Sumber Daya Mineral. Edisi 02 .
Sugiri, A.Md., S.Pd. dan Moh. Supriyadi. (2006). Pemrograman Sistem Pengendali dengan Delphi. Yogyakarta: C.V. Andi Offset

Wilman Septina. (2013). Solar Cell: Struktur dan Cara kerja.

https://teknologisurya.wordpress.com/das ar-teknologi-sel-surya/prinsip-kerja-sel$\underline{\text { surya/ }}$ 